\title{
IDENTIFIKASI AWAL POLYAROMATIC HYDROCARBONS (PAHs) DI UDARA AMBIEN SERPONG-JAKARTA
}

\section{PRE-IDENTIFICATION OF POLYAROMATIC HYDROCARBONS (PAHs) IN SERPONG-JAKARTA AMBIENT AIR}

\author{
Dewi Ratnaningsih¹, Hari W' ${ }^{1}$, Esrom $\mathrm{H}^{1}$, Jetro $\mathrm{S}^{1}$ \\ (Diterima tanggal 23-09-2013; Disetujui tanggal 02-01-2014)
}

\begin{abstract}
ABSTRAK
Pengukuran Polyaromatic hydrocarbons (PAHs) dengan menggunakan Passive Air sampling (PAS) bertujuan untuk identifikasi awal pencemaran PAHs di udara ambien. Passive air sampling yang berisi poliurethan foam (PUF) berbentuk lingkaran dengan diameter $14 \mathrm{~cm}$ dan ketebalan $1.35 \mathrm{~cm}$ dipaparkan selama 42 hari di Serpong dan di Jakarta untuk menangkap sampel udaradalam bentuk gas secara pasif. Metode ekstraksi dan pemurnian dilakukan terhadap sampel yang ada didalam PUF, dan proses selanjutnya analisis menggunakan GCMS. $\sum_{15}$ PAH di Jakarta terdeteksi dengan konsentrasi $74 \mathrm{ng} / \mathrm{m}^{3}$ sedangkan di Serpong terdeteksi dengan konsentrasi $34 \mathrm{ng} / \mathrm{m}^{3} \cdot \sum_{15} \mathrm{PAH}$ tersebut terdeteksi dengan pola distribusi yang mirip namun dengan konsentrasi $\sum_{15}$ PAH di Jakarta dua kali lebih tinggi dibandingkan di Serpong. Kemiripan pola distribusi konsentrasi PAHs menunjukkan kemiripan sumber pencemar PAHs. Hasil rasio individual PAH menunjukkan bahwa sumber pencemar PAH di dua lokasi tersebur mayoritas berasal dari minyak bumi.
\end{abstract}

Kata Kunci: Passive Air Sampling, PAHs, PUF, ekstraksi organik, GCMS

\begin{abstract}
The aim of this study is in order to identified contamination of PAHs in the ambient air by using passive air sampler. Poliurethane Foam (PUF) with diameter $14 \mathrm{~cm}$ and thickness $1,35 \mathrm{~cm}$ were used for collecting gas phase of ambient air passively by using Passive Air Sampling. PUF were exposured in Serpong and Jakarta during 42 days. PUF were extracted by organic solvent and purified before analysis by using GCMS. Ambient air concetration of $\sum_{15} P A H$ in Jakarta was detected $74 \mathrm{ng} / \mathrm{m} 3$ two times higher than in Serpong $34 \mathrm{ng} / \mathrm{m} 3$ with similir distribution pattern of PAHs in those two locations. Similar distribution pattern reflected similar polution source of PAHs. Rasio calculation of individual PAHs indicated that PAHs pollution in ambient air majority resulted from petroleum.
\end{abstract}

Keyword: Passive Air Sampling, PAHs, PUF, organic extracted, GCMS.

\section{PENDAHULUAN}

Polycyclic aromatic hydrocarbons (PAHs), atau dikenal sebagai poly-aromatic hydrocarbons atau polynuclear aromatic hydrocarbons, merupakan senyawa organik yang berpotensi menjadi pencemar di lingkungan baik di udara, air, sedimen maupun tanah. Senyawa ini dihasilkan dari proses pembakaran tidak sempurna dan atau proses tekanan tinggi.
PAHs dengan kandungan dua sampai delapan cincin aromatik terdiri dari ratusan senyawa individual di lingkungan, namun hanya 16 senyawa yang termasuk dalam daftar pencemar prioritas oleh US-EPA (United StatesEnvironmental Protection Agency) yang umum dijadikan target dalam pemantauan lingkungan yaitu naphthalene, acenaphthylene, acenaphthene, fluorene, phenanthrene,

${ }^{1}$ PUSARPEDAL-Kementerian Lingkungan Hidup. Kawasan Puspiptek gedung 210, J1 Raya Puspiptek-Serpong,
Tangerang Selatan-Banten. Email:dewirinie@gmail.com 
anthracene, fluoranthene, pyrene, benzo[a]anthracene, chrysene,benzo(a) pyrene, benzo[b]fluoranthene, benzo[k] fluoranthenedibenz(ah)anthracene, benzo(ghi) perylene, dan indeno(1,2,3-cd)pyrene [1]. Agency for Toxic Subtances and Disease Registry (ATSDR) menentukan 17 senyawa PAHs yang terdiri semua senyawa dalam daftar EPA (tidak termasuk naphthalene) ditambah dengan coronene dan benzo(e) pyrene [4].

Individual PAH sangat bervariasi, dan memiliki sifat tidak mudah larut dalam air atau bersifat lipofilik sehingga mudah terakumulasi dalam jaringan lemak, sebagian mudah menguap di udara namun sebagian besar cenderung terserap di dalam bahan partikulat organik. PAH yang lebih berat akan berasosiasi dengan bahan partikel diudara sehingga jatuhnya partikel partikel tersebut merupakan jalur terjadinya pencemaran. PAH dengan cincin aromatik lebih besar atau sama dengan lima akan dominan berada di partikel halus $(<2,5$ um) sedangkan PAH dengan dua atau tiga cincin aromatik hampir keseluruhanya berada dalam fase uap dan $\mathrm{PAH}$ dengan empat cincin aromatik berada pada posisi tengah fase gas dan partikel halus [2].

Sebagai polutan, PAHs ini telah menjadi perhatian karena beberapa senyawa telah diidentifikasi sebagai karsinogenik, mutagenik, dan teratogenik. Toksisitas PAHs secara struktural sangat tergantung dari isomernya, dengan formula dan jumlah cincin yang sama dapat bervariasi toksisitasnya. Salah satu senyawa PAHs yaitu benzo(a) pyrene merupakan senyawa yang bersifat karsinogenik, menyebabkan gangguan pada kulit manusia dan hewan serta menyebabkan dampak berbahaya terhadap pertumbuhan dan reproduksi [3].Manusia yang menghirup campuran PAHs dalam periode waktu yang lama dapat terkena kanker. Beberapa PAH dapat menyebabkan kanker pada binatang percobaan, jika menghirup udara tercemar PAHs maka akan mengalami kanker paruparu, terkontaminasi PAH lewat makanan terjadi kanker perut, dan terpapar dikulit terjadi kanker kulit [4].

Sumber pencemar PAHs di lingkungan ada dimana mana, selain berasal dari bahan bakar fosil dan biomasa, PAHs juga terbentuk dari hasil proses pembakaran tidak sempurna bahan bakar yang mengandung karbon seperti pembakaran kayu, batubara, solar, aspal, lemak, tembako dan dupa. Pembakaran dupa ditempat tempat ibadah, maupun dirumah beresiko terhadap kanker [5].PAHs juga berasal dari kebakaran hutan, asap rokok, proses pemasakan makanan dengan suhu tinggi seperti daging panggang, ikan asap [6]. PAHs juga berada dalam minyak, batubara dan timbunan tar [3].

Senyawa PAH di udara berpotensi untuk tersebar dan juga menjadi pencemar pada mahkluk hidup melalui proses inhalasi. Paparan PAHs yang terjadi di daerah urban pada umumnya melalui aktifitas antropogenik seperti emisi kendaraan bermotor, pembakaran batubara dan bahan bakar fosil untuk pembangkit listrik, penyulingan minyak bumi, pembakaran jerami dan kayu bakar, proses industri, manufaktur kimia, tumpahan minyak dan ter batubara [7]. Sumber pembakaran yang berbeda akan menghasilkan distribusi individual PAHs yang berbeda dimana isomer tersebut dihasilkan. Oleh karena itu pembakaran batubara akan menghasilkan jenis 
pola PAH yang berbeda dengan pembakaran motor atau kebakaran hutan. Perbedaan komponen tersebut sangat berguna untuk indikator sejarah pembakaran yang terjadi.

Mengingat mudahnya PAHs terpapar di lingkungan dan dampak negatif yang ditimbulkan terhadap kesehatan serta minimnya data PAHs diudara ambien maka perlu inisiasi mengetahui pencemaran PAHs yang terjadi di udara ambien dan sumber pencemarnya. Kegiatan ini bertujuan untuk identifikasi awal keberadaan 15 senyawa PAHs yang terdiri dari acenaphthylene (Acy), acenaphthene(Ace), fluorene(Fl), phenanthrene(Phe), anthracene(Ant), fluoranthene(Flu), pyrene(Pyr), benzo[a] anthracene(BaA), chrysene(Chr), benzo(a) pyrene(BaP), benzo(b)fluoranthene $(B b F)$, benzo(k)fluoranthene(BkF), dibenz(ah) anthracene(DahA), benzo(ghi) perylene(BghiP), dan indeno(1,2,3-cd) pyrene $(\operatorname{Icd} P)$, di udara ambiendengan menggunakan passive air sampling (PAS).

\section{METODOLOGI}

Pengambilan sampel PAHs di udara ambien dengan menggunakan Passive Air Sampler
(PAS) yang berisi Polyurethane foam (PUFdisk)yang berbentuk lingkaran dengan diameter $14 \mathrm{~cm}$ dan ketebalan 1,35 cmdilakukan di dua lokasi sampling yaitu di Serpong dan Jakarta. PUF-disk yang dikembangkan oleh KORDI-AMETEC berdasarkan PUF tipe Harner tersebut ditempatkan ditengah wadah berbentuk dua kubah stainless stell dengan rongga diantara dua kubah agar udara mengalir ke PUF (Gambar1). Kubah tersebut berfungsi untuk melindungi PUF dari tetesan air hujan atau presipitasi, sinar matahari UV langsung, dan deposisi partikel [8]. Wadah juga berfungsi untuk mengurangi ketergantungan laju sampling dengan kecepatan angin yang dihasilkan selama periode sampling. Pengambilan sampel udara secara pasif dengan PUF akan lebih dominan dalam bentuk fase gas dengan kecepatan 3-5 m3/hari meskipun senyawa kimia yang berasosiasi dengan partikel halus juga mungkin tertangkap di PUF tersebut [9]. Paparan PUF di udara ambien dilakukan pada periode ahkir bulan Agustus sampai awal bulan Oktober 2010 selama kurun waktu 42 hari, yaitu paparan di Serpong mulai tanggal 24 Agustus sampai 5 Oktober 2010 dan di
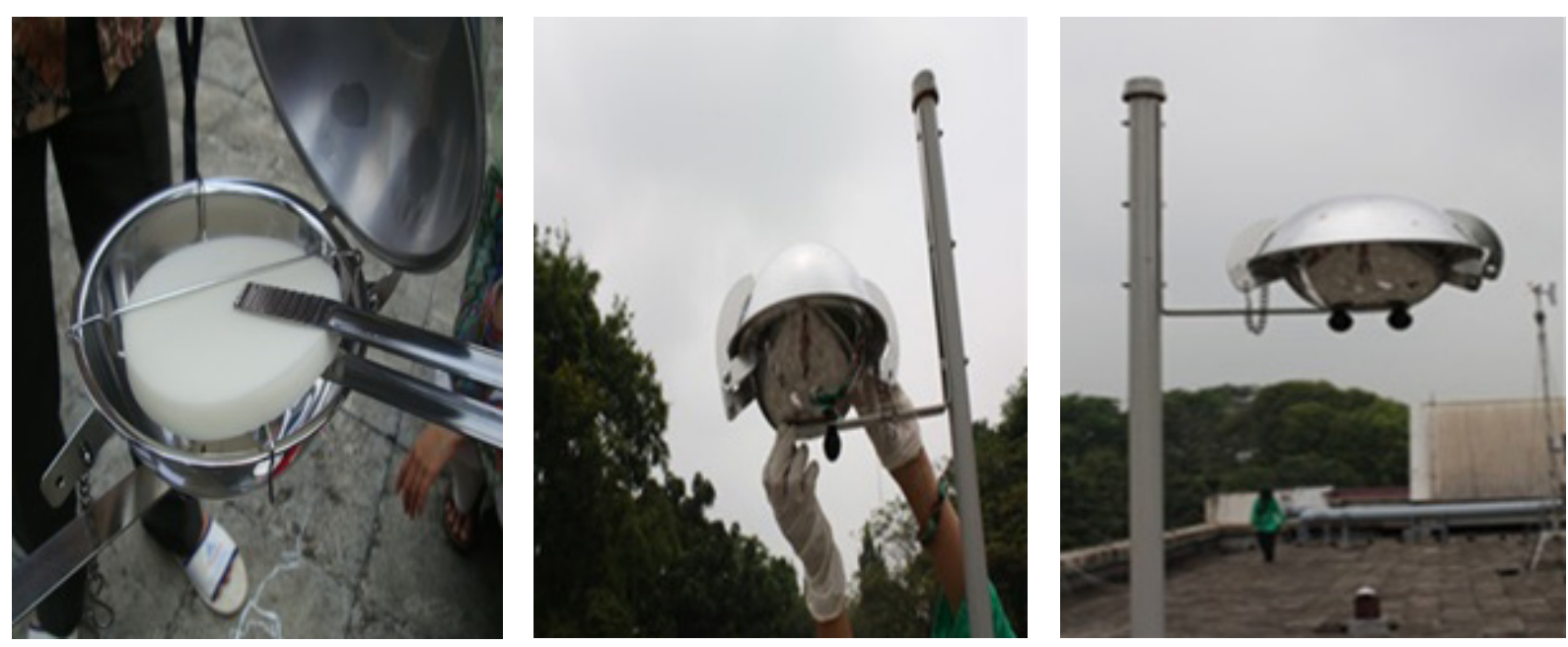

Gambar 1. Pemasangan $P U F$ dalm $P A S$ untuk pengambilan sampel $P A H s$ di diudara ambien 
Jakarta mulai tanggal 23 Agustus sampai 4 Oktober 2010. Untuk menjaga keamanan dan memudahkan pengawasan selama paparan PUF berlangsung maka PAS ditempatkan diatap gedung Pusarpedal Serpong pada koordinat S 6 $13,34.01$ ”, T 106 50'5.14" dan diatap gedung BPLHD Jakarta pada koordinat S 6²1'0.27" T:10640'3.43”. Lokasi penempatan PUF di Jakarta berdekatan dengan jalan raya dan jalan layang bebas hambatan sedangkan lokasi Serpong diasumsikan mempunyai aktifitas kegiatan manusia atau transportasi yang lebih rendah dibandingkan dengan di Jakarta.

PUF yang telah dipaparkan diudara kemudian dilakukan ekstraksi dengan pelarut organik hexane/diklorometan dan dilakukan pemurnian dengan dilewatkan pada kolom silica/alumina sebelum di analisis dengan menggunakan Gas Chromatografi Mass Spectrometry (GCMS) HP GC 5890, MS 5972 dengan kondisi GC sebagai berikut : Colom DB-5MS (30m x 0,25mm x 0,25 $\mu \mathrm{m}$ film), temperatur program:temperatur awal 60 ${ }^{\circ} \mathrm{C}$ selama 2 menit, kenaikan temperatur $6^{\circ} \mathrm{C} /$ min sampai $300{ }^{\circ} \mathrm{C}$, temperatur ahkir $300{ }^{\circ} \mathrm{C}$ ditahan selama 13 menit. Gas pembawa $\mathrm{He}$ $1 \mathrm{ml} / \mathrm{min}$, temperaturinjektor $300{ }^{\circ} \mathrm{C}$, mode injeksi dengan splitless, volume injeksi 2 $\mu 1$. Kondisi MS : temperatur interfase 280 ${ }^{\circ} \mathrm{C}$, scanning range 30-300 amu, 2 cycle/sec, ionization voltage $70 \mathrm{eV}$, metode :Selected Ion Monitoring (SIM) [10].

\section{HASIL DAN PEMBAHASAN}

Hasil pengukuran PAHs dengan menggunakan passive air sampling (PAS) di Jakarta dan Serpong menunjukkan bahwa dari $\sum_{15}$ senyawa PAH yang diukur semuanya terdeteksi di udara ambien di dua lokasi tersebut dengan konsentrasi yang bervariasi. Jumlah $\sum_{15}$ PAH yang diukur di Serpong sebesar $34 \mathrm{ng} /$ $\mathrm{m}^{3}$ sedangkan di Jakarta sebesar $74 \mathrm{ng} / \mathrm{m}^{3}$. Konsentrasi total PAH di Jakarta dua kali lebih besar dibandingkan dengan di Serpong yang didominasi oleh senyawa phenantrenedi kedua lokasi tersebut (gambar 1).

Total $\sum_{15}$ PAH yang terdeteksi di udara ambien tersebut tidak berbeda jauh dengan hasil pemantauan yang dilakukan pada waktu bersamaan dari negara lain di Asia Pasific yaitu di India Utara (urban $69,1 \mathrm{ng} / \mathrm{m}^{3}$; rural $27,9 \mathrm{ng} / \mathrm{m}^{3}$ ), Vietnam (urban 71,9 ng/m 3 ; rural $24,2 \mathrm{ng} / \mathrm{m}^{3}$ ), Thailand (urban $57,8 \mathrm{ng} / \mathrm{m}^{3}$,rural $36.3 \mathrm{ng} / \mathrm{m}^{3}$ ), China Selatan (urban 27,8 ng/m $\mathrm{m}^{3}$, rural 13,5 ng/m ${ }^{3}$ ), kecuali China Utara (urban $130 \mathrm{ng} / \mathrm{m}^{3}$, rural 98,4 $\mathrm{ng} / \mathrm{m}^{3}$ ) dan Malaysia (urban 18,1 ng/m³ , rural $2 \mathrm{ng} / \mathrm{m}^{3}$ ) [10].

Phenenthrene (Phe) merupakan senyawa individual PAH yang terdeteksi paling tinggi dengan nilai sebesar $29 \mathrm{ng} / \mathrm{m}^{3}$ di daerah urban Jakarta dan dideteksi sebesar 15,8 $\mathrm{ng} / \mathrm{m}^{3}$ didaerah rural Serpong, diikuti oleh fluroranthene dan pyrene. Fluoranthene terdeteksi di Jakarta dan Serpong secara berurutan dengan nilai $11,7 \mathrm{ng} / \mathrm{m}^{3}$ dan 6,2 $\mathrm{ng} / \mathrm{m}^{3}$, sedangkan untuk pyrene di Jakarta terdeteksi 13,4 ng/m $\mathrm{m}^{3}$ dan di Serpong 4,6 ng/ $\mathrm{m}^{3}$ (Gambar 3). Keberadaan senyawa tersebut diudara ambien utamanya berada pada fase gas, dan PUF yang digunakan lebih cenderung berinteraksi dengan gas, meskipun partikel yang sangat halus juga dimungkinkan untuk ditangkap oleh PUF tersebut [9]. Phenantrene diasumsikan sebagai tapak dari buangan asap kendaraan bermotor [11] Informasi tersebut mendukung hasil yang diperoleh karena lokasi penempatan sampling secara fisik baik 


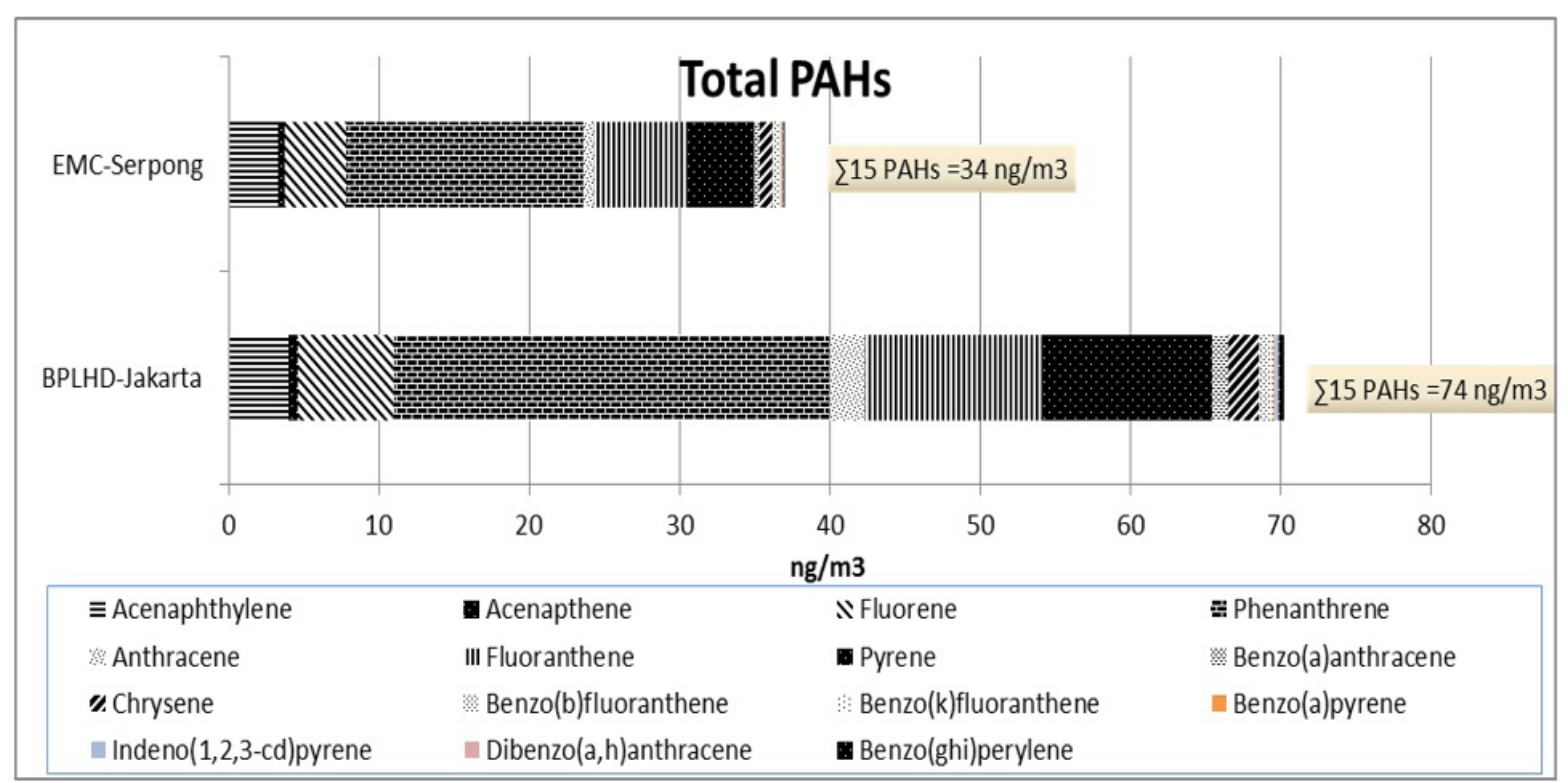

Gambar 2. Hasil Total PAHs yang terdeteksi di daerah Serpong dan Jakarta pada periode pemantauan tahun 2010

di jakarta maupun di Serpong tidak terlepas dari pengaruh oleh asap kendaraan bermotor, dengan intensitas kegiatan transportasi di Jakarta yang lebih tinggi dibandingkan dengan di Serpong. Hasil ini juga memberikan indikasi bahwa titik pantau Serpong tidak sesuai dijadikan sebagai daerah perwakilan rural yang belum terpengaruh aktifitas kendaraan bermotor, karena lokasi titik pantau berada di kawasan perkantoran.

Gambar 4 menunjukkan bahwa hasil pemantauan PAHs untuk senyawa
Acenapthilen, Flurene, antracene dna Benzo(a) antracene terdeteksi di Jakarta dan Serpong dengan konsentrasi masih dibawah $7 \mathrm{ng} / \mathrm{m}^{3}$ dengan urutan Fluorene $>$ acenap htylene $>$ anthracene $>$ benzo(a) anthracene. Konsentrasi senyawa tersebut terdeteksi lebih tinggi di BPLHD Jakarta dibandingkan dengan di Pusarpedal Serpong.

Senyawa individual PAHs seperti acenapthene, benzo(b) fluoranthene, benzo(K) fluoranthene, benzo(a)pyrene fluoranthene, indeno(1,2,3cd)pyrene, dibenzo(ah) anthracene, benzo(ghi)

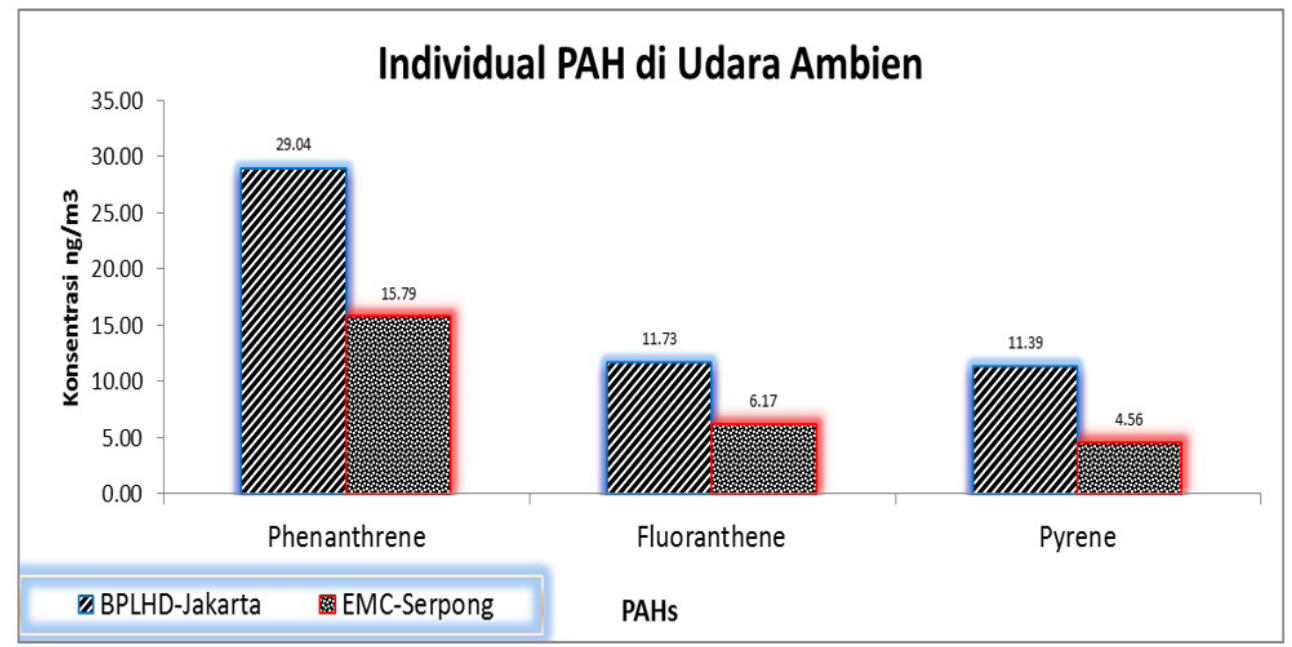

Gambar 3. Individual PAH pada kisaran nilai 4,6 -29 ng/m 


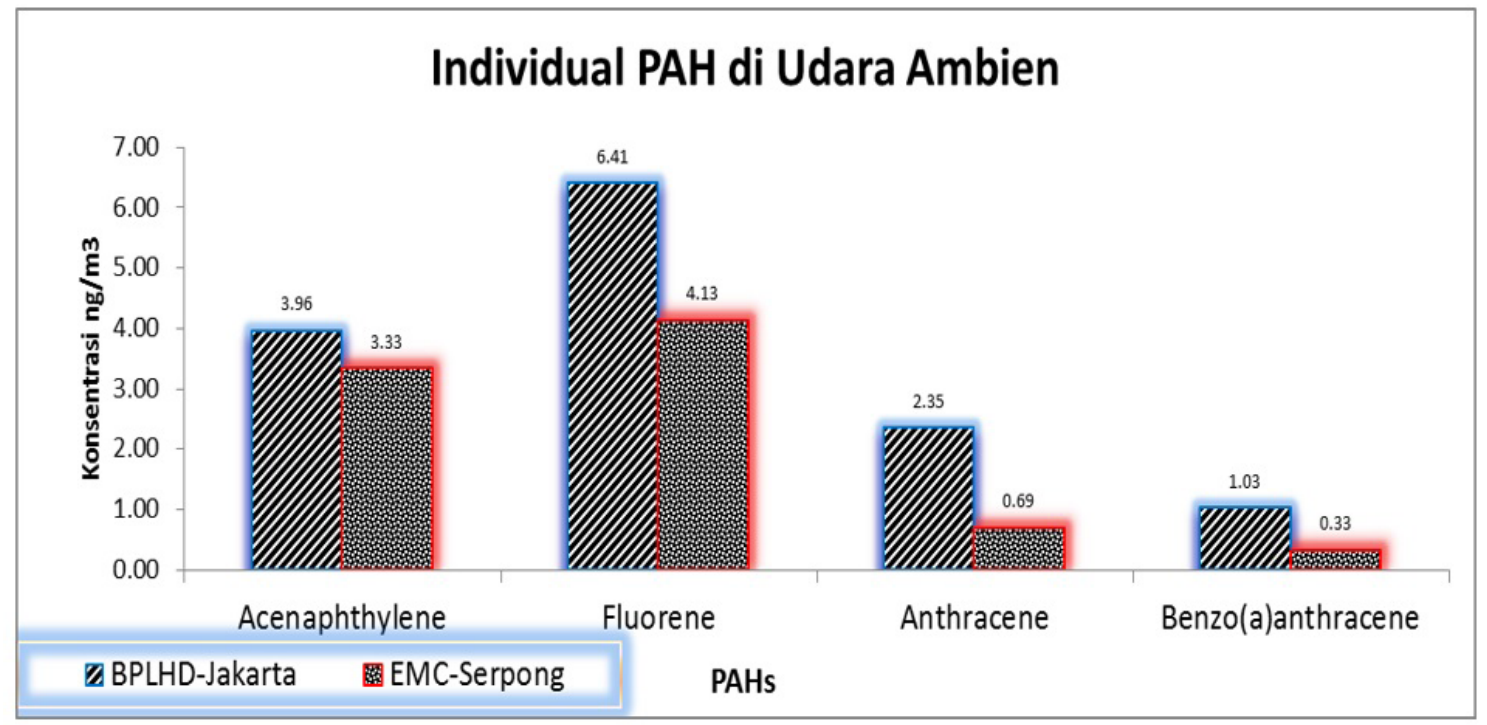

Gambar 4. Individual PAH pada kisaran nilai $0,33-6,41 \mathrm{ng} / \mathrm{m}^{3}$

perylene terdeteksi pada konsentrasi diwah 1 $\mathrm{ng} / \mathrm{m}^{3}$ yaitu pada kisaran $0,01-0,75 \mathrm{ng} / \mathrm{m}^{3}$ (gambar 5). Konsentrasi terendah terdeteksi untus senyawa dibenzo( $(a, h)$ anthracene di udara ambien serpong sebesar 0,01 ng/ $\mathrm{m}^{3}$. Konsentrasi PAHs yang rendah ini umumnya untuk PAHs dengan jumlah cincin aromatik yang banyak ( $\geq 4$ cincin) atau berat molekul yang besar. Meskipun senyawa ini terdeteksi dengan kisaran yang rendah namun perlu mendapat perhatian mengingat bahwa senyawa tersebut bersifat karsinogenik. Akumulasi melalui paparan dari udara secara terus menerus dapat menyebabkan dampak negatif yang membahayakan kesehatan manusia.

Pola distribusi individual PAH dari 15 senyawa PAHs yang dideteksi di Jakarta dan Serpong dapat dilihat pada Gambar 6. Hasil identifikasi yang terbatas di dua lokasi tersebut menunjukkan bahwa pola distribusi PAHs di udara ambien yang diambil di BPLHD-Jakarta dan Pusarpedal-Serpong relatif mirip. Pola distribusi PAHs yang mirip di kedua lokasi tersebut memberikan indikasi kemiripan sumber pencemar PAHs di kedua lokasi tersebut.

Rasio dari masing masing individu PAH juga dapat membantu menggambarkan sumber pencemaran PAHs tersebut.Rasio antara Ant/ (Ant+Phe), BaA/(BaA+Chr), Flu/(Flu+Pyr) dan IcdP/(IcdP+BghiP) digunakan untuk membedakan antara sumber petrogenik dan sumber petrolitik [12]. Ant/(Ant+Phe) $<0,1$ menggambarkan sumber minyak bumi, sementara rasio $>0.1$ merefleksikan pembakaran. Rasio Flu/(Flu+Pyr) $<0,4$ mengindikasikan minyak bumi, antara 0,4 dan 0,5 implikasi pada pembakaran bahan bakar fosil cair dan rasio $>0,5$ merupakan karakteristik dari pembakaran biomasa dan pembakaran batubara [13]. Rasio IcdP/ $($ IcdP + BghiP $)<0,2$ dan $\mathrm{BaA} /(\mathrm{BaA}+\mathrm{Chr})<0,2$ mengindikasikan minyak bumi dan sumber petrogenik. $\mathrm{BaA} /(\mathrm{BaA}+\mathrm{Chr})$ antara 0,2 dan 0,35 dan IcdP/(IcdP+BghiP) antara 0,2 dan 0,5 PAH biasanya berasal dari pembakaran minyak bumi (pembakaran fosil cair, pembakaran bahan bakar kendaraan bermotor dan minyak mentah). Ketika IcdP/(IcdP+BghiP) $>0,5$ 


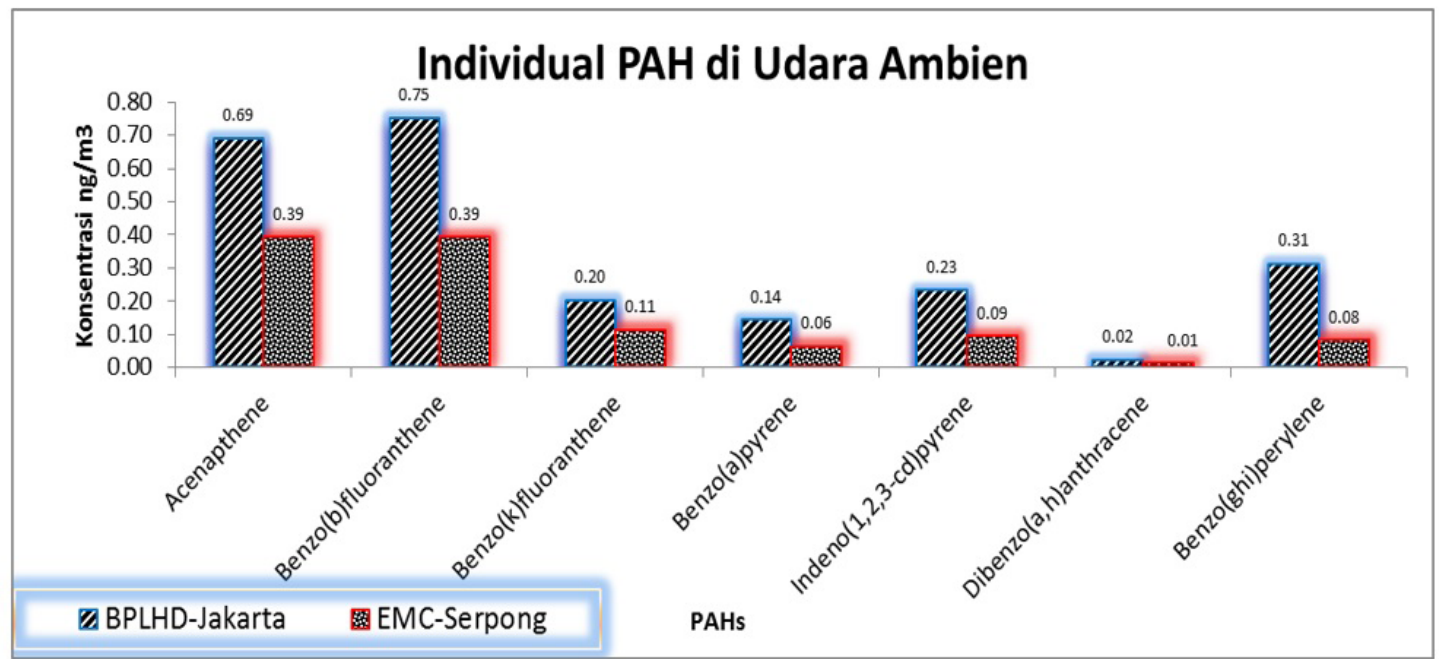

Gambar 5. Individual PAH dengan kisaran konsentrasi 0,01- 0,75 ng/m³.

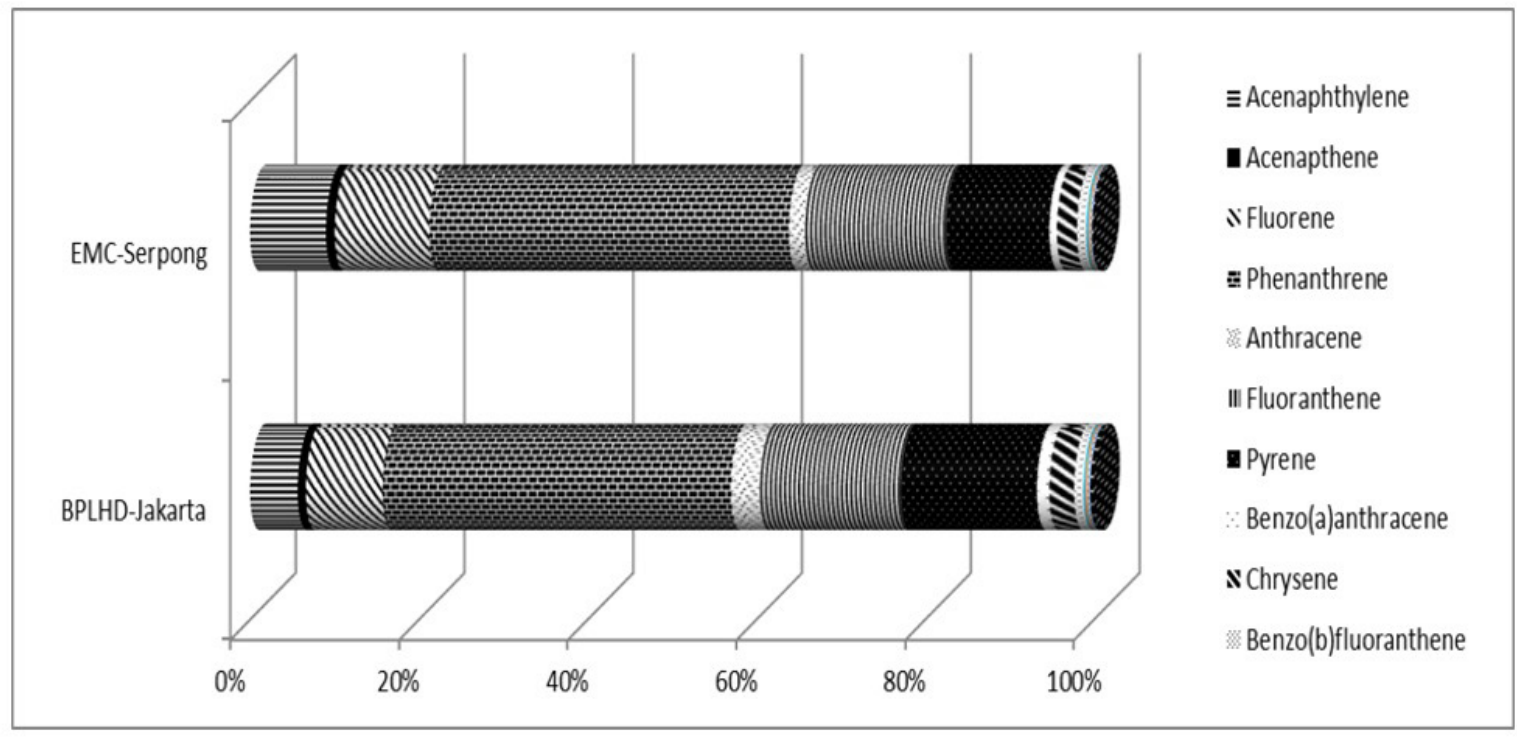

Gambar 6. Pola distribusi PAHs di Serpong dan Jakarta

dan $\mathrm{BaA} /(\mathrm{BaA}+\mathrm{Chr})>0,5$ hal ini secara jelas menunjukkan kontribusi dari batu bara, semak ataupun kayu [13].

Berdasarkan data hasil pengukuran PAHs yang masih terbatas di dua lokasi tersebut terlihat indikasi bahwa sumber pencemar PAHs berasal dari minyak bumi dengan rasio Ant/(Ant+Phe) seberar 0,07 di Jakarta dan 0,04 di Serpong, demikian juga jika dilihat dari rasio Flu/(Flu+Pyr) di Jakarta sebesar 0,37 dan di Serpong sebesar 0,47 dari pembakaran minyak bumi. Hasil rasio
$\mathrm{BaA} /(\mathrm{BaA}+\mathrm{Chr})$ sebesar 0,3 (Jakarta) dan 0,27 (Serpong) serta rasio IcdP/(IcdP+BghiP) sebesar 0,06 Jakarta dan 0,11 di Serpong juga menunjukkan sumber dari minyak bumi. Hal ini sesuai dengan kondisi lokasi sampling yang merupakan daerah dengan kontribusi sumber pencemar dari kendaraan bermotor yang dominan apalagi untuk titik pantau Jakarta yang berdekatan dengan jalur padat lalu lintas serta jalur layang bebas hambatan. Meskipun lokasi Serpong pada awalnya relatif rural dibandingkan Jakarta namun perkembangan 
Serpong telah mengarah menjadi daerah urban dengan semakin meningkat aktifitas dan jumlah penduduk yang berimplikasi juga pada semakin banyaknya jumlah kendaaran bermotor. Hal tersebut menjadi sumber pencemar PAHs yang utama di udara ambien.

Berdasarkan hasil pengukuran yang terbatas tersebut maka perlu dicermati bahwa hasil pembakaran bahan bakar kendaraan bermotor sangat berpotensial untuk mencemari udara dengan parameter parameter organik seperti senyawa PAHs yang beberapa diantaranya sebagai karsinogenik. Kondisi tersebut belum mempertimbangkan pencemaran dari senyawa organik mudah menguap berbahaya lainnya yang sangat dimungkinkan dapatdihasilkan dari proses pembakaran minyak bumi. Penggunaan bensin tanpa timbal pada kendaraan bermotor yang tidak dilengkapi katalisator ataupun tehnologi yang mendukung tidak menjamin bahwa asap kendaraan yang dibuang ke lingkungan telah aman terhirup manusia, karena dimungkinkan tersembunyi bahaya yang lain dari pencemaran bahan organik berbahaya seperti benzene, toluene dsb. Hasil identifikasi ini sebagai indikasi bahwa dengan menggunakan PAS dapat dilakukan pemantauan PAHs dengan waktu paparan yang relatif lama dan dapat memberi informasi sumber pencemar PAHs yang dominan di udara ambien. Dari sampel yang terbatas ini belum terlihat sumber pencemar PAHs yang berasal dari pembakaran biomasa ataupun pembakaran batubara sehingga perlu dilakukan perluasan lokasi identifikasi. Pada lokasi pemantauan di daerah kebakaran hutan akan mengasilkan rasio yang sangat berbeda dengan yang dihasilkandidaerah urban, dan untuk itu perlu dicermati lebih banyak data lagi sehingga dapat dihasilkan informasi yang lebih mewakili yang dapat digunakan untuk membantu upaya kebijakan pengendalian pencemaran udara.

\section{SIMPULAN}

Konsentrasi $\sum_{15}$ PAHs di Jakarta dideteksi sebesar $74 \mathrm{ng} / \mathrm{m}^{3}$, dua kali lebih tinggi dibandingkan dengan di Serpong dengan nilai $34 \mathrm{ng} / \mathrm{m} 3$. Pola distribusi PAHs pada dua lokasi Jakarta dan Serpong relatif mirip sehingga dapat menggambarkan adanya sumber pencemaran yang relatif sama. Hasil dari rasio Ant/(Ant+Phe), $\mathrm{BaA} /(\mathrm{BaA}+\mathrm{Chr})$ dan IcdP/(IcdP+BghiP) mengindikasikan bahwa sumber pencemar PAHs baik di Serpong dan di Jakarta relatif sama dan mayoritas berasal dari minyak bumi yang bisa dipaparkan ke udara melalui asap kendaraan bermotor.

Perlu inventarisasi lebih lanjut pencemaran PAHs yang terjadi di lingkungan, karena paparan PAHs dapat menimbulkan dampak negatif yang efeknya jangka panjang terhadap kesehatan manusia dan mahkluk hidup yang lain. Inventarsasi pencemaran PAHs juga perlu dilakukan di lokasi lokasi lain sehingga dapat diketahui kontribusi dominan pencemaran PAHs apakah berasal dari aktifitas transportasi, industri, pertanian, kebakaran hutan, dan sumber lainya. Hasil inventarisai tersebut sangat bermanfaat untuk mendukungupaya kebijakan pengendalian pencemaran udara.

\section{UCAPAN TERIMAKASIH}

Ucapan terimakasih disampaikan kepada Korean Ocean Researc (KORDI) melalui program AMETEC-UNU Workshop di Geoje 
Korea yang telah menfasilitasi pelaksanaan kegiatan termasuk dalam pelaksanaan ilmu dan pengetahuan dan analisis. Ucapan terimakasih juga disampaikan kepada Pusarpedal-KLH yang telah memfasilitasi dan mendukung terlaksananya kegiatan pengambilan sampel, BPLHD DKI Jakarta yang menyediakan lokasi penempatan sampler serta semua pihak yang telah membantu terselenggaranya kegiatan ini.

\section{DAFTAR PUSTAKA}

(1) EPA, 2003. EPA appendix A to 40 CFR, Part 423-126 Priority Pollutants. diakses 11 Juni 2013. http://www.epa. gov/region1/npdes/permits/generic/ prioritypollutants.pdf/.

(2) European Commission, Scientific Committee on Food, Polycyclic Aromatic Hydrocarbons - Occurrence in foods, dietary exposure and health effects.December 4, 2002.

(3) Persistent Bioacumulative and Toxic Chemical Program. diakses 24 Juni 2013. http://www.epa.Gov/pbt/pubs/ benzo.htm/.

(4) Agency for Toxic Substances and Disease Registry, Polycyclic Aromatic Hydrocarbons (PAHs)". 1996

(5) Incense link to cancer". BBC News 2001-08-02. diakses 23 juni 2013. http://news.bbc.co.uk /2/hi/ health/1467409/.

(6) Ikenna O.C. and Osuoha Nnenna. Identification and Quantitative Analysis of carcinogenik PAH components in four different species of traditionally smoked fish purchased in Port Harcourt metropolis, rivers state Nigeria. Journal of Applied Sciences in Environmental Sanitation. 2012; 7 (3): 215-219.
(7) Peng C, Chen WP, Liao XL, Wang ME, Ouyang ZY, Jiao WT, et al. Polycyclic aromatic hydrocarbons in urban soils of Beijing; Status, sources, distribution and potential risk. Environ Pollution. 2011; 159:802-8.

(8) Pozo K, Tom Harner, M Shoeib, Roberto U, Ricardo B, Oscar P, et.al. Passive-Sampler derived Air Concentration of Persistent Organic Pollutants on a North-South Transect in Chile. Environ. Sci. Technol. 2004.p. 38,6529-6537.

(9) Harner T, K Pozo, T Gouin, Am Macdonald, H Hung, J Cainey, A Peters. Global pilot study for persistent organic pollutants (POPs) using PUF disk passive air samplers. Environ. Poll. 2005. p.144, 445-452

(10) AMETEC/UNU workshop. Passive Air sampling: Long range transport of pollutants. Geoje, Korea; 2010.

(11) Harrison, R.M, smith, D.J.T, Luhana. Source apportionment of atmospheric polycyclic aromatic hydrocarbons collected from an urban location in Birmingham. UK. Environ. Sci technol. 1996. p. 30, 825-832.

(12) Zhang HB, Luo YM, Wong MH, Zhao QG, Zhang GI. Distributions and concentration of PAHs in Hongkong soils. Environ Pollut;2006. p. 141:10714.

(13) Yunker MB, Maxdonald RW, Vingarzan R, Mitchell RH, Goyette D, Sylvestre S. PAHs in the Fraser River basin: a critical appraisal of PAH ratios as indicators of PAH sources and composition. Org Geochem; 2002. p. 33:489-515. 